\title{
PRÁTICAS DE LEITURA E COMPREENSÃO ORAL EM LÍNGUA INGLESA: ADAPTAÇÃO DE GÊNEROS TEXTUAIS PARA DIFERENTES NÍVEIS
}

\author{
Reading and listening practices in English: adaptation of text genres for different \\ levels
}

\author{
Denise Akemi HIBARINO, DELEM-UFPR e FACEL ${ }^{1}$ \\ Graziella Araujo de Oliveira LAPKOSKI . Celin - UFPR ${ }^{2}$
}

\begin{abstract}
RESUMO: A integração das habilidades de leitura, escrita, oralidade e compreensão oral são preocupações constantes do professor de Língua Inglesa. No entanto, ao adotar uma abordagem comunicativa, o professor, muitas vezes, desenvolve atividades mais voltadas para a oralidade. Não raro, os alunos apresentam dificuldades com estratégias de leitura e durante os exercícios de compreensão oral. Desta forma, o objetivo deste relato é mostrar como é possível integrar estas duas últimas habilidades e, principalmente, compartilhar atividades baseadas em diferentes gêneros textuais (fábulas, histórias em quadrinhos, filmes, etc), adaptadas para diferentes níveis. Como conclusão, enfatizamos a importância de explorar os diferentes gêneros textuais presentes no cotidiano do aluno e do professor.
\end{abstract}

PALAVRAS-CHAVE: Integração de Habilidades; Leitura; Compreensão Oral;

Elaboração de Atividades; Gêneros Textuais

\begin{abstract}
Integrating the reading, writing, speaking and listening skills are constant concerns in the English teacher practice. However, when adopting a communicative approach, the teacher, most of the times, develops activities emphasizing the speaking skill. Not surprisingly, the students show difficulties in relation to reading strategies and during listening tasks. Hence, this report aims to demonstrate how it is possible to integrate these last two skills and, most importantly, share activities based on different text genres (fables, comic strips, movies, etc), adapted to different levels. In conclusion, it is highlighted the relevance of exploring the different text genres which are part of students' and teacher's daily lives.
\end{abstract}

KEY WORDS: Skills Integration; Reading; Listening; Activity Design; Text Genres

\footnotetext{
${ }^{1}$ Mestre em Letras pela UFPR e professora de Língua Inglesa no DELEM-UFPR e FACEL

${ }^{2}$ Mestre em Letras pela UFPR
} 


\section{Introdução}

Este relato ${ }^{3}$ surgiu da nossa experiência enquanto professoras de língua inglesa (LI) durante a troca de ideias sobre o preparo de aulas de diferentes níveis do Celin (Centro de Línguas e Interculturalidade - UFPR), desde o básico até o avançado.

Duas dificuldades frequentemente relatadas em conversas informais por vários professores é a prática de leitura em sala e a elaboração de atividades extra de compreensão oral, e como fazer a integração destas habilidades com as outras de forma significativa para os alunos.

Teóricos como Celce-Murcia (2001) e Brown (2001 e 2007), entre outros, ao enfatizarem os pressupostos da abordagem comunicativa, chamam a atenção para a integração das habilidades desde o início do processo de aprendizagem (CELCEMURCIA, p.8). Embora a questão "input e output" (recepção e produção) ainda seja controversa, Brown (2007, p.293) diz parecer óbvio que tanto um quanto o outro são processos, em graus variados de distribuição complementar, que fazem parte da aprendizagem de uma segunda língua. Segundo este autor, "a integração das habilidades de linguagem na vida real faz com que eles [os alunos] percebam a relação entre as diversas habilidades e oferece ao professor bastante flexibilidade na criação de lições motivadoras e

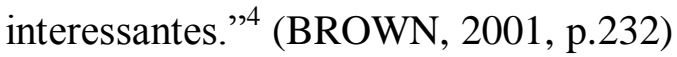

Entendemos que as quatro habilidades (oralidade, compreensão oral, leitura e escrita) são igualmente importantes para quem deseja adquirir proficiência na língua. No entanto, enquanto professores, sabemos que, dependendo do rendimento do grupo, existe a necessidade de complementar as atividades de sala com mais input, algumas vezes de leitura, outras de compreensão oral, para dar ao aluno mais subsídios e segurança para o desenvolvimento das produções textuais.

Esta complementação nem sempre é fácil de ser realizada, em especial por questões de tempo hábil, uma vez que ela se dá pela busca e adequação de textos autênticos que refletem as situações do cotidiano. Estes processos normalmente exigem do professor mais

\footnotetext{
3 As atividades descritas já foram apresentadas previamente no evento 10th BRAZ-TESOL National Convention, promovido pela associação dos professores de língua inglesa no Brasil, em 2006, e posteriormente revisadas para este relato.

4 “...real-life integration of language skills, gets them to perceive the relationship among several skills, and provides the teacher with a great deal of flexibility in creating interesting, motivating lessons."
} 
tempo de preparo de aula do que o usual. Além disso, muitas vezes, a integração das habilidades tende a ser ignorada, por parecer difícil de ser realizada. Sendo assim, pensando em dar algumas ideias para ajudar a desmistificar a complexidade desta integração e facilitar o preparo de novos materiais, elaboramos algumas atividades que, esperamos, possam servir de ponto de partida:

\section{Atividades}

\section{Activity 1: histórias em quadrinhos do Garfield}

\section{Nível: pré-intermediário}

As tirinhas do Garfield são textos autênticos interessantes que trazem uma linguagem simples e situações do cotidiano de forma bem-humorada. Selecionamos as duas tirinhas abaixo para trabalhar com a leitura e a oralidade. A compreensão oral também é trabalhada, pois o aluno tem que compreender a história contada para responder as questões.

A atividade é realizada em duplas.

\section{Student A:}

1- Read the comic strip and tell the story to your partner:

Tirinha do Garfield disponível em:

http://garfield.com/comics/vault.html?yr=2005\&addr=050514

\section{Student B :}

1- Read the comic strip and tell the story to your partner:

Tirinha do Garfield disponível em:

http://garfield.com/comics/vault.html?yr=2005\&addr=050511 


\section{Activity 2: Competição de fábulas}

\section{Nível: pré-intermediário}

O uso de fábulas adaptadas em língua inglesa é recurso bem produtivo, pois muitos alunos já tem um conhecimento prévio delas. O foco desta atividade é a leitura e a oralidade.

Procedimento:

a) Entregar uma fábula ${ }^{5}$ para cada aluno;

b) Organizar os alunos em grupos de 3 ou 4;

c) Cada aluno lê sua fábula e reconta aos colegas;

d) Todos devem pensar sobre a moral de cada uma das fábulas;

e) Os alunos devem encontrar a moral de cada história escrita no quadro ou coladas nas paredes;

f) O grupo vencedor é aquele que conseguir relacionar o maior número de histórias com a sua moral.

\section{The Goat and the Goatherd}

A GOATHERD had sought to bring back a stray goat to his flock. He whistled and sounded his horn in vain; the straggler paid no attention to the summons. At last the Goatherd threw a stone, and breaking its horn, begged the Goat not to tell his master. The Goat replied, "Why, you silly fellow, the horn will speak though I be silent."

\section{Do not attempt to hide things which cannot be hid.}

\section{The Eagle and the Arrow}

An Eagle was soaring through the air when suddenly it heard the whiz of an Arrow, and felt itself wounded to death. Slowly it fluttered down to the earth, with its life-blood pouring out of it. Looking down upon the Arrow with which it had been pierced, it found that the shaft of the Arrow had been feathered with one of its own plumes. "Alas!" it cried, as it died.

\section{We often give our enemies the means for our own destruction.}

\footnotetext{
${ }^{5}$ As duas fábulas utilizadas nesta atividade foram retiradas do site do Projeto Gutenberg disponível em:< http://www.gutenberg.org/files/21/21-h/21-h.htm>. Acesso em: 10 jul.2006.
} 


\section{Activity 3:}

\section{Nível: Básico - Pré-intermediário}

Esta atividade foi adaptada da revista Speak up, publicação voltada para os alunos de LI. Como o texto informativo trata de um assunto pertinente para discussão em sala, elaboramos perguntas sobre a opinião dos alunos sobre o vegetarianismo, para serem respondidas antes de ler o texto informativo:

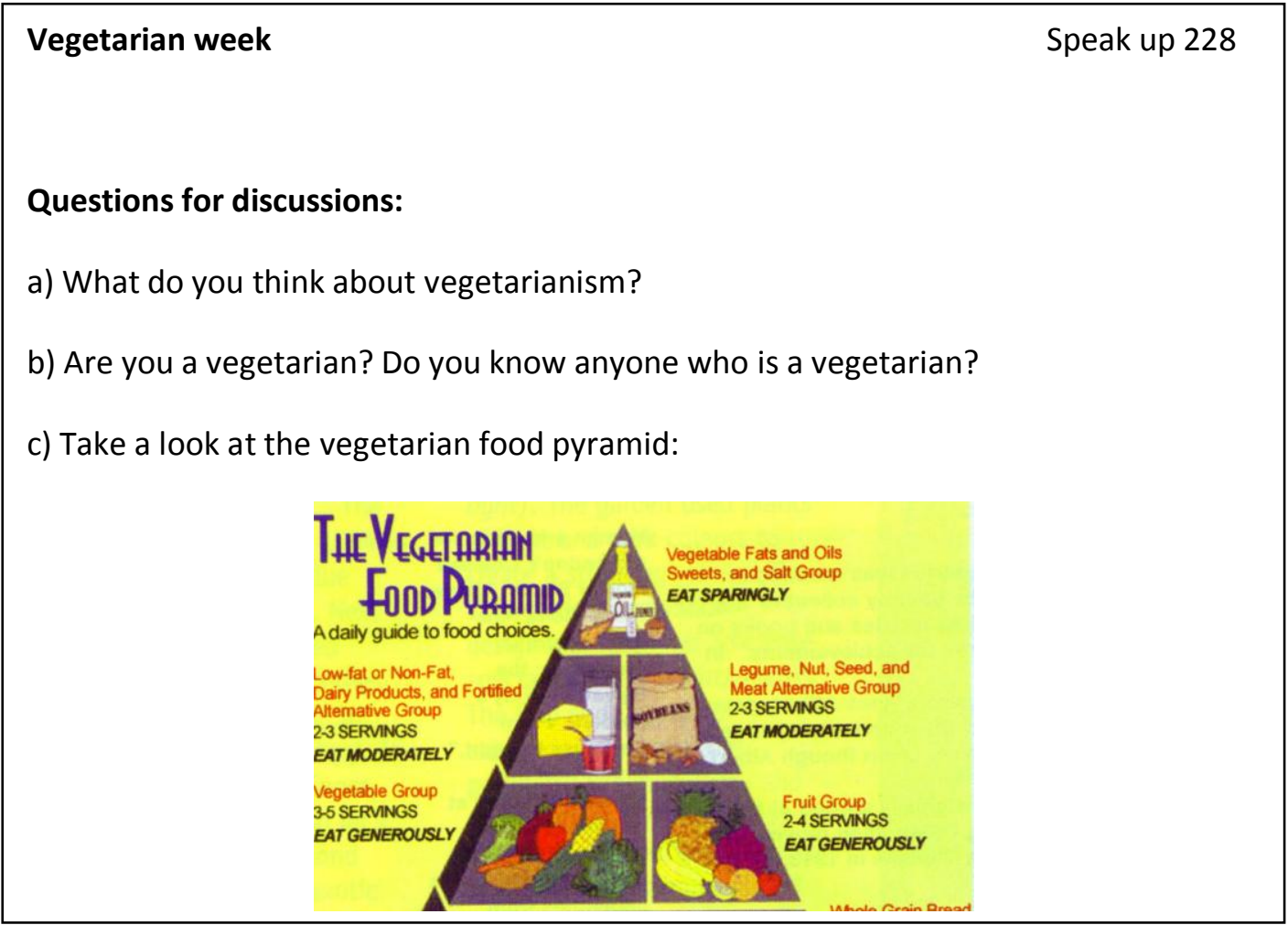

Após discussão, perguntamos aos alunos se eles tem conhecimentos de eventos que promovem os hábitos vegetarianos na cidade, assim como quem participa, quem organiza este tipo de evento. A partir das respostas dos alunos, aproveitamos para falar de um evento chamado "Semana Vegetariana na Grã-Bretanha". Em seguida, aproveitamos o CD de áudio que acompanha a revista para trabalhar com a seguinte atividade: 
Now, listen to the Vegetarian week in Britain and complete the exercise:

a) The period in which the Vegetarian week happens:

b) The number of Britons who become vegetarian every week:

c) A vegetarian diet can reduce health problems like: , diabetes and

d) Two kinds of food/beverage which receive animal products in their elaboration: and

Em seguida, incluímos o seguinte quadro para cada aluno descrever sua dieta ideal:

Imagine how a one-day health diet would be for you. After that, tell your
partner to complete the chart for you:
\begin{tabular}{|l|c|c|c|c|c|}
\hline Areakfast & Snack & Lunch & Snack & Dinner & Snack \\
\hline & & & & & \\
\end{tabular}

\section{Activity 4: Filme}

\section{Nível: Básico}

Na primeira parte desta atividade, o aluno ouve a cena inicial do filme Casamento Grego sem ver a imagem, para realizar a atividade abaixo. O foco aqui é a compreensão oral. 


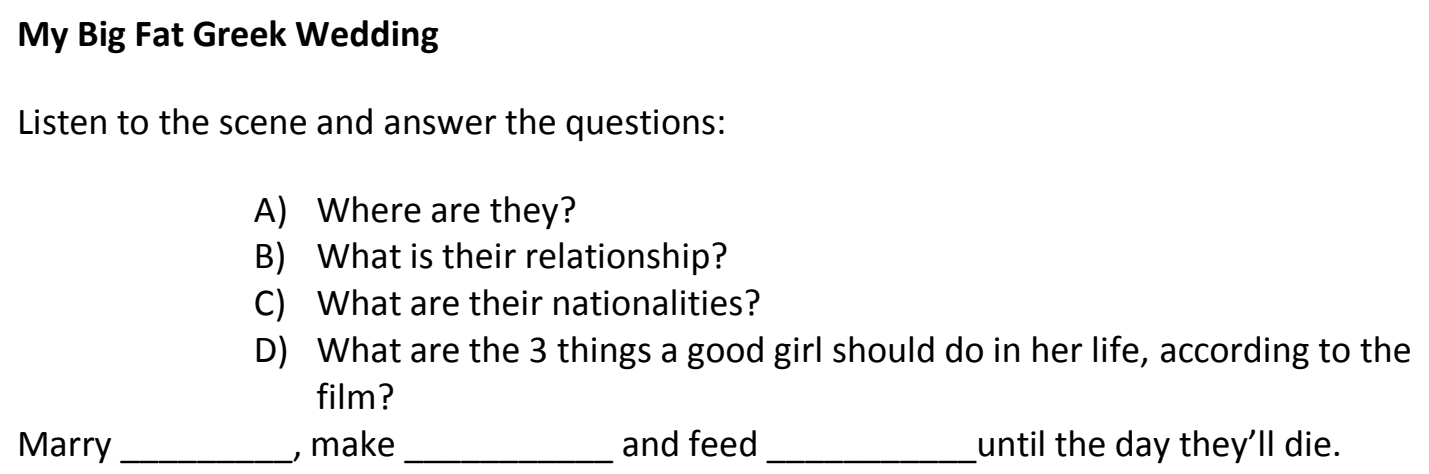
until the day they'll die.

Depois disso, é feita uma breve discussão com a turma sobre o filme, para garantir que todos saibam do que se trata.

O professor chama a atenção dos alunos para a personagem da mãe da noiva, para fazer a conexão entre o filme e a leitura proposta a seguir.

Na segunda parte da atividade, voltada para a leitura, os alunos devem ler o texto individualmente. A seguir, a dinâmica é feita com a sala toda e participa quem quer. Os alunos vão dizer o que entenderam do texto, se concordam ou não com o que leram e de qual dica mais gostaram.

\section{Learning to deal with mother-in-laws}

Planning a wedding (and even after the wedding!) can cause some family stress, particularly with your future mother-in-law. Fortunately, there are some ways to deal with the stress of the new mother.

Mothers who are connected to their sons often have difficulty when it is time for them to get married, particularly as the wedding date nears, and sometimes even after the wedding day. It is difficult for them to think that their son is marrying another woman who will be the focus of their life. Your future mother-in-law may be rude or she does not want to be involved in any aspects of the wedding. Usually, these actions are because they're envious, anxious and they think any woman is good enough for their son. Here are some tips to deal with her:

* Try to be patient.

* Invite her to a luncheon with your parents so that they can get to know each other.

* Send her flowers on her birthday.

* Send her a nice e-mail or leave her a message on the answering machine.

* Explain to her that you are in love with her son and have only the best of intentions.

If these options do not work, try to maintain a distance from your future mother-in-law. 
Esta última atividade é um exemplo de como seria possível fazer a integração de mais habilidades, usando o mesmo material. Nela, estamos combinando apenas as habilidades de compreensão oral e leitura, conforme mencionado acima, mas poderíamos incluir a oralidade e a escrita, mostrando a cena seguinte ao que eles ouvem, só que desta vez sem som, para os alunos discutirem o que está acontecendo a seguir na história, ou imaginar o que os personagens devem estar dizendo. No final, poderíamos pedir aos alunos que escrevessem suas dicas de como lidar com a sogra, a partir das ideias do texto. Imaginamos que neste momento, o leitor já deve ter em mente algumas outras possibilidades. E se isso é verdade, acredito termos atingido nosso objetivo.

\section{Conclusão}

As atividades apresentadas são baseadas em material de fontes variadas e deixam claro a nossa preocupação com a integração da leitura e compreensão oral com as outras habilidades e entre si. Nossa intenção é mostrar as possibilidades de conseguir materiais adaptáveis na internet, em revistas e mesmo em outros materiais didáticos. Também queremos lembrar que é possível utilizar somente parte de um gênero textual, pois muitas vezes, o professor tem a preocupação de utilizar um gênero na íntegra, como: tocar a música inteira, assistir todo o filme, ou ler o artigo tal como foi publicado, algo que pode de alguma forma inviabilizar a atividade extra. Se for necessário, o professor pode fazer a contextualização antes da atividade, ou depois, conforme o caso. O fundamental é estabelecer uma ligação lógica entre as atividades de uma habilidade e de outra; o que pode ser feito nas instruções escritas, nas instruções verbais, em uma discussão com a turma toda, ou o professor pode apresentar uma linha de raciocínio estabelecendo as conexões necessárias entre as atividades propostas para as diferentes habilidades, por exemplo.

A utilização de diferentes gêneros textuais é extremamente relevante na atualidade devido aos diferentes estilos de aprendizagem encontrados em sala e também por mostrar os usos da linguagem em contextos variados. De acordo com Crawford (2002, p. 87) "É essencial que professores reconheçam os diferentes backgrounds, experiências e estilos de 
aprendizagem que seus alunos trazem para a aula de língua, e o impacto que estas experiências têm naqueles aspectos do input que são prováveis de serem internalizados."6

Neste sentido, a utilização de diferentes gêneros permite envolver mais os alunos e mostrar que aprender a LI não significa somente ler sempre os mesmos gêneros textuais tampouco escutar os diálogos artificiais presentes nos diversos livros didáticos. Além disso, temos que considerar que o mundo de hoje e do futuro é um mundo multimídia e precisamos ajudar nossos alunos a tirar o maior proveito possível dos recursos e informações encontrados nas diversas fontes. A este respeito, Crawford (2002, p. 85), por exemplo, defende a ideia de que os materiais devem incluir um componente audiovisual porque estes materiais "podem criar um ambiente de aprendizado que é rico em informação cultural e linguística sobre a língua alvo."7

Finalmente, neste relato evidenciamos como é possível fazer a integração das habilidades, ressaltando sua importância para o aprendizado de LI, já discutidas, como mencionado no início, por autores como Celce-Murcia (2001) e Brown (2001 e 2007) e, mais importante ainda, mostramos algumas formas de explorar os diferentes gêneros textuais de maneira criativa e interessante na sala de aula de língua inglesa.

\section{REFERÊNCIAS}

BROWN, H. D. Teaching by Principles: An Interactive Approach to language Pedagogy. $2^{\text {nd }}$ ed. New York: Longman, 2001.

BROWN, H. D. Principles of language Learning and Teaching. $5^{\text {th }}$ ed. New York: Longman, 2007.

CASAMENTO grego. Direção de Joel Zwick. Estados Unidos/Canadá: Gold Circle Films. Dist. Europa Filmes, 2002. 1 filme. (95 min): son., color, 16mm.

CELCE-MURCIA, M. Language teaching approaches: an overview. In: CELCEMURCIA, M. Teaching English as a second or foreign language. Boston: Heinle, 2001, p.3-11.

\footnotetext{
6 "It is essential for teachers to recognize the different backgrounds, experiences and learning styles that students bring to the language classroom, and the impact these experiences have on what aspects of the input are likely to become intake."

7 "...can create a learning environment that is rich in linguistic and cultural information about the target language."
} 
CRAWFORD, J. The Role of Materials in the Language Classroom. In: Methodology in Language Teaching: An Anthology of Current Practice. New York: CUP, 2002. 